\title{
ARSA Gene
}

National Cancer Institute

\section{Source}

National Cancer Institute. ARSA Gene. NCI Thesaurus. Code C103930.

This gene is involved in the metabolism of cerebroside sulfate. 